
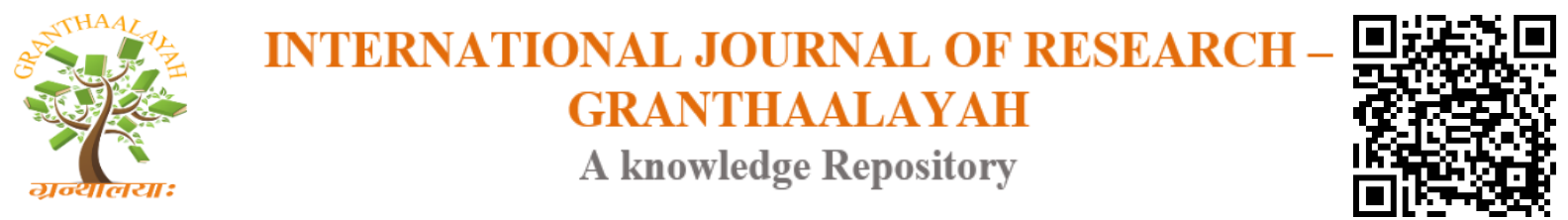

Science

\title{
ANTIOXIDANT AND ANTIMICROBIAL POTENTIAL OF COCCINEA CORDIFOLIA
}

\author{
Saumendu Deb Roy ${ }^{* 1}$, Suvakanta Dash ${ }^{2}$, Jashabir Chakraborty ${ }^{3}$ \\ ${ }^{* 1}$ Bharat Technology, Uluberia, Howrah, West Bengal, India \\ ${ }^{2}$ Regional Institute of Pharmaceutical Science and Technology, Agartala, Tripura, India \\ ${ }^{3}$ Girijananda Chowdhury Institute of Pharmaceutical Science, Guwahati, Assam, India
}

\begin{abstract}
In the present study, Coccinea cordifolia root was extracted with various solvents according to their increasing order of polarity and the extracts were subjected to preliminary phytochemical investigation. The extracts were then subjected to antioxidant assay using FTC, TBA, DPPH and Reducing Power assay as models and Antimicrobial assay. The Methanolic extract of the plant root has shown good antioxidant and antimicrobial activity among the extracts under study. The findings of the study here justify the traditional claim against Coccinea cordifolia root.
\end{abstract}

Keywords: Coccinea Cordifolia; Traditional Medicine; Antioxidant; Antimicrobial.

Cite This Article: Saumendu Deb Roy, Suvakanta Dash, and Jashabir Chakraborty. (2018). "ANTIOXIDANT AND ANTIMICROBIAL POTENTIAL OF COCCINEA CORDIFOLIA." International Journal of Research - Granthaalayah, 6(9), 309-320. https://doi.org/10.5281/zenodo.1443487.

\section{Introduction}

Coccinea cordifolia is an annual creeper, found spreading on ground and twilling around the trees and supports. The stems are pentagonal in shape. Leaves are triangular or pentagonal in shape, dentate and have a length of 2 to 5 inch and breath of 2 inch. Flowers are monocieus. Flowers are white in colour. Fruits are slimy in touch, pulpy and are barrel shaped, 1 to 2 inch in length. Fruits are green in color when it is raw form which turns to scarlet red on ripening. It also possesses about ten white stripes on its posterior portion. This fruit posses numerous seeds inside. Its roots are long and resemble tuberous roots. The roots also contain Resins, few alkaloids, starch, gum, fatty acid and carbonic acid. Presence of minerals like calcium, iron and phosphorus are also reported. As per Ayurveda the drug is reported to be Kapha, Pitta suppressant. It is reported to be a good wound healer and anti-inflammatory drug and is also a good appetizer and helps improve digestion. It is a good laxative and stimulated liver for proper bile secration. It also acts as good anti-amoebic drug and a blood purifier. It is also helpful in expelling the extra amount of mucous accumulated in the respiratory tract. It is also useful in polyuria and is used in diabetes where it is said to control 
glucose level $\mathrm{n}$ blood. It also opens up pores in the skin so as to facilitate easy secration of sweat thus expelling out body toxins. ${ }^{1}$

Steroids, triterpenoids, glycosides, saponins, tannins, alkaloids, saponins, phenols and carbohydrates are the reported chemical moieties present in the plant. The total phenolic content was found to be within the range of $38.25 \pm 0.86(\mathrm{mg} / \mathrm{gm})$ to $72.58 \pm 0.36(\mathrm{mg} / \mathrm{gm})$ whereas the alkaloidal content was in-between $12.52 \pm 0.48(\mathrm{mg} / \mathrm{gm})$ and $24.45 \pm 0.19(\mathrm{mg} / \mathrm{gm})$ for the methanolic extract. ${ }^{2}$

Ability to utilize oxygen helps us in metabolizing carbohydrates, fats and proteins; however it also costs us heavily. Oxygen is a highly reactive species and is a part of potentially damaging molecule commonly known as "Free radicals". Free radicals can attack the healthy cells of the body and the cells in-turn may lose their structure and function. ${ }^{3}$ Free radical production occurs continuously in the body as a part of normal cellular functions. But, excessive production of free radicals triggered by endogenous or exogenous source may lead to diseased conditions. ${ }^{4}$

A free radical may be defined as a molecule capable of independent existence having an unpaired electron in an atomic orbital. Many of these radicals are highly reactive and may either donate or accept an electron, hence acting as oxidants or reductants. Most important free radicals for a number of diseased conditions are oxygen derivatives like superoxide or hydroxyl radical. ${ }^{4}$

Plants and plant products contains a large number of free radical scavenging molecules, like phenolic compounds (e.g. Flavonoids, Coumarins, Quinones, Lignans, Tannins and Phenolic acids,), nitrogen containing compounds (e.g. Amines and Alkaloids), Vitamins, Terpenoids etc. which are known for their antioxidant activity. Studies shows many of these compounds to possess other therapeutic activities like antitumor, anti-atherosclerotic, anti-mutagenic, anti-inflammatory, antibacterial, or antiviral activities to some extent. ${ }^{5}$

Natural antioxidants are found to be associated with lower risks of cancer, diabetes, and other diseases. Synthetic antioxidants like BHA (butylated hydroxyl-anisole) and BHT (butylated hydroxyl-toluene) are used these days due to their effectiveness and low cost. But, the safety of synthetic antioxidants is of concern. And so, considerable interest has grown for the use of antioxidants from natural source. ${ }^{6}$

\section{Materials and Methods}

\section{Plants Material}

Benzene (BZ), Diethyl Ether (DE), Chloroform (CH), Ethylacetate (EA) and Methanol (MT) extracts of both Coccinea Cordifolia root were subjected to test in these experiments.

\section{Preparation of Extract}

Around $1 \mathrm{~kg}$ of both the powdered drug material were packed in two different soxhlet assembly and extracted using the successive extraction method using various solvents (Benzene, Diethyl Ether, Chloroform, Ethyl acetate and Methanol) in order of their increasing polarity. All through before extraction with a new solvent, the powdered materials were air dried to remove traces of the previous solvent. ${ }^{7}$ 
Each extract thus obtained was concentrated and dried under reduced pressure using Eyela Rotary Evaporator (Japan) at a temp. ranging between $42-45^{\circ} \mathrm{C}$. The dried extracts were then stored in dessicator for future use.

\section{Preliminary Phytochemical Analysis}

The preliminary phytochemical test for the different extracts of the plant drugs was performed by standard methods. ${ }^{8,9}$

\section{Antioxidant Activity of Different Extracts of Coccinea Cordifolia Root}

\section{Chemicals}

TBA (Thiobarbituric acid) was procured from Loba Chemie, India. DPPH (1,1-Diphynyl-2-picryl hydrazyl), NADH and nitroblue tetrazolium (NBT) were all procured from Sigma chemicals, St. Louis, USA., Ethylene diamine tetra acetic acid (EDTA), trichloroacetic acid, hydrogen peroxide, ferrous sulphate, dimethyl sulphoxide ascorbic acid, mannitol, potassium dihydrogen phosphate, potassium hydroxide used in the experiment were of analytical grade and procured from Ranbaxy fine chemicals.

\section{Ferric Thiocyanate Assay (FTC)}

By FTC method, we determined the amount of peroxide at the initial stage and secondary stage of lipid peroxidation. The FTC assay was carried out using methods as described by Kikuzaki and Nakatani. ${ }^{10}$ Solutions of various concentration of extracts were added to $4 \mathrm{ml}$ of $99.5 \%$ ethanol, $8.0 \mathrm{ml}$ of $0.02 \mathrm{M}$ phosphate buffer ( $\mathrm{pH} 7.0$ ), $4.1 \mathrm{ml}$ of $2.51 \%$ linoleic acid in $99.5 \%$ ethanol, and $3.9 \mathrm{ml}$ of distilled water, in a screw-capped vial $(38 \times 75 \mathrm{~mm})$ and were placed in an oven at $40{ }^{0} \mathrm{C}$ and incubated in the dark. For measuring the antioxidant activity, $0.1 \mathrm{ml}$ of the reaction mixture was taken in a test tube $(13 \times 150 \mathrm{~mm})$, to it added $9.7 \mathrm{ml}$ of $75 \%(\mathrm{v} / \mathrm{v})$ aqueous ethanol, followed by $0.1 \mathrm{ml}$ of $30 \%$ aqueous ammonium thiocyanate and $0.1 \mathrm{ml}$ of $0.02 \mathrm{M}$ ferrous chloride in $3.5 \%$ hydrochloric acid. After three minutes of addition of ferrous chloride to the reaction mixture, the absorbance was measured spectrophotometrically (Shimadzu 1601 Double beam, Japan) at 500 $\mathrm{nm}$ where ascorbic acid was used as a positive control. ${ }^{10}$

\section{Thiobarbituric Acid Method (TBA)}

The Thiobarbituric Acid analysis was performed according to the method described by Chang et.al. ${ }^{11}$ The samples prepared for FTC method were used here too. To the required quantities of the sample solution, $2.0 \mathrm{ml}$ of aqueous thio-barbituric acid (TBA) solution and $1.0 \mathrm{ml}$ of $20 \%$ aqueous trichloro-acetic acid (TCA) were added. The mixtures were placed on boiling water bath for 10 minutes, cooled and then centrifuged at $3000 \mathrm{rpm}$ for around 20 minutes and absorbance of the supernatant liquid was measured at $532 \mathrm{~nm}^{12}$ using Shimadzu 1601 Double beam spectrophotometer, Japan. Both the methods (FTC and TBA) has described antioxidant activity by percent inhibition;

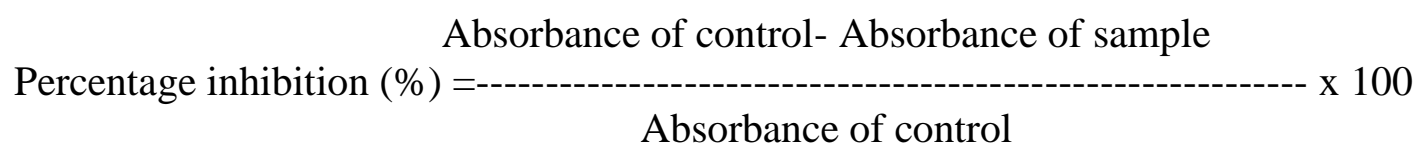




\section{Reducing Power Assay (RP)}

Reducing power assay was performed according to the method described by Oyiazu (1986). The required concentrations of various extracts were suspended in distilled water, to them added 2.5 $\mathrm{ml}$ of $0.2 \mathrm{M}$-phosphate buffer (pH6.6), and $2.5 \mathrm{ml}$ of $\mathrm{K}_{3} \mathrm{Fe}(\mathrm{CN})_{6}(1 \% \mathrm{w} / \mathrm{v})$. The mixtures were then incubated at $50{ }^{0} \mathrm{C}$ for around $20 \mathrm{~min}$. Then, $2.5 \mathrm{ml}$ of TCA $(10 \% \mathrm{w} / \mathrm{v})$ were added to each. The resultant mixtures were then centrifuged at $3000 \mathrm{rpm}$ for around $10 \mathrm{~min}$. and the upper layers of these solutions $(2.5 \mathrm{ml})$ were mixed with distilled water $(2.5 \mathrm{ml})$ and $0.5 \mathrm{ml} \mathrm{FeCl} 3(0.1 \% \mathrm{w} / \mathrm{v})$, and the absorbance of the resultant mixtures were measured at $700 \mathrm{~nm}$ against blank sample. Ascorbic acid was used as standard antioxidant compound for this study. ${ }^{13}$

\section{Free Radical Scavenging Activity by 1,1-Diphenyl-2-picryl-hydrazil (DPPH)}

The free radical scavenging activity of different extracts were measured by 1,1-diphenyl-2-picrylhydrazil (DPPH), following the procedure described by Blois. ${ }^{14} 0.1 \mathrm{M}$ solution of DPPH. in ethanol was prepared, $1 \mathrm{ml}$ of this solution was added to each of the extract solution $(3 \mathrm{ml})$ in water at different concentrations. The mixtures were then shaken vigorously and were allowed to stand at room temperature for $30 \mathrm{~min}$. Absorbance of the resultant mixtures were measured spectrophotometrically at $517 \mathrm{~nm}$ (Shimadzu 1601 Double beam, Japan). Higher free radical scavenging activity of the reaction mixtures were indicated by lower absorbance values. ${ }^{15}$ Ascorbic acid was used as standard in this assay.

$$
\text { DPPH. scavenging effect }(\%)=\left[\left(\mathrm{A}_{\mathrm{o}}-\mathrm{A}_{1} / \mathrm{A}_{\mathrm{o}}\right) \times 100\right]
$$

Where,

$\mathrm{A}_{\mathrm{o}}$, is the absorbance of the control reaction mixture, and $\mathrm{A}_{1}$, is the absorbance of the samples at various concentrations.

\section{Antimicrobial Assay of Methanolic Extract of Coccinea Cordifolia Root}

\section{Microorganisms}

The microbial species were obtained from Microbiology Department of Jaduvpur University, Kolkata. The collected species were S. aureus, E.coli, K. pneumoniae, S.typhi sp., V. cholera, P. aeruginosa, B. subtilis and $S$. faecalis. The cultures of bacteria were maintained on nutrient agar slants at $4{ }^{\circ} \mathrm{C}$ and sub-cultures were transferred to nutrient broth, 24 hours before testing.

\section{Preservation of Bacterial Strains}

Strains of S. aureus, E.coli, K. pneumoniae, S.typhi, V. cholera, P. aeruginosa, B. subtilis and S. faecalis were preserved using slant cultures at $4^{\circ} \mathrm{C}$ temperature. The routine sub culture of Gram +ve strains were done using nutrient agar media and for Gram -ve strains bromothymol blue lactose agar media was used. ${ }^{16}$

\section{Standard Antibiotic}

Lincomycin (Lyka Labs, India) was used as standard drug for the study. The pure sample of the drug was received as gift sample from M/S Lyka Labs, India. 


\section{Preparation of Impregnated Discs of Extract and Standard Antibiotics}

Discs with $7.25 \mathrm{~mm}$ diameter were prepared by punching of whatman no. 1 filter paper and all the discs were sterilized by dry heat at $160^{\circ} \mathrm{C}$ for an hour in batches in screw capped Bijou bottles. The mathanolic extracts of Coccinea Cordifolia root was weighed and dissolved in sterile distilled water to make the required solutions of concentration $128-2000 \mu \mathrm{g} / \mathrm{ml}$. Similarly the stock solution of the control antibiotic (lincomycin) within the range of $0-1000 \mu \mathrm{g} / \mathrm{ml}$ were prepared by dissolving the required amount of the drugs in sterile distilled water. All the prepared stock solutions were then kept at $4^{\circ} \mathrm{C}$. Now, for preparing antibiotic impregnated discs, $1.0 \mathrm{ml}$ of the stock solutions of the antibiotic was added separately to sterile Bijou bottles containing 100 discs each. The same procedure was followed for preparing impregnated discs of the plant extracts and their isolated compounds. The discs were used while wet and can be stored for further use at $4^{\circ} \mathrm{C}$, as they can retain the moisture and potency for at least 3 months in the screw capped Bijou bottles. 17,18

\section{Antimicrobial Assay}

The antimicrobial assay was performed by disc diffusion method. Nutrient agar plates with inoculum size of $10^{5}-10^{6} \mathrm{cfu} / \mathrm{ml}$ of the microorganisms were used. Previously prepared discs (Concentration 128-2000 $\mu \mathrm{g} / \mathrm{ml}$ ) and antibiotic (concentration 0-1000 $\mu \mathrm{g} / \mathrm{ml}$ ) were placed aseptically on petridishes. All the petridishes were then incubated at $37^{\circ} \mathrm{C} \pm 2^{\circ} \mathrm{C}$ for 18 hour. After 18 hours, the activity was recorded by measuring the zone of inhibition on the petridishes around the discs. The zone of inhibitions thus observed, were measured using a transparent ruler and recorded with reference to the zone of inhibition of the standard drug. Lincomycin was taken as standard drug for this study. ${ }^{19,20}$

\section{Minimum Inhibitory Concentration (MIC)}

MICs were determined using standard agar dilution method. ${ }^{21}$ The methanolic extract was dissolved in $0.5 \mathrm{ml}$ of dimethyl sulphoxide and then further diluted using sterilized distilled water. The drug solution thus prepared was then added to the molten nutrient agar in different tubes to give a concentration in the range of $0-128 \mu \mathrm{g} / \mathrm{ml}$ and then subsequently increasing it two folds up to $2000 \mu \mathrm{g} / \mathrm{ml}$. The $\mathrm{pH}$ of the tubes were adjusted to 7.2 to 7.4 and transferred to sterile petridishes. Bacterial cell suspensions $(10 \mu \mathrm{l})$ were then inoculated on the petridishes using sterile bacterial planter. Number of cfu inoculated onto the petridishes was $10^{5}$ for all the microbial strains. All the inoculated petridishes were then incubated for 18 hours at $37^{\circ} \mathrm{C} \pm 2^{\circ} \mathrm{C}$. The petridish with lowest concentration which did not show any visible growth of microorganism upon incubation was considered as MIC for that particular microbial strain. The petridishes containing sterile distilled water and Lincomycin solution, served as negative and positive control respectively.

\section{Result and Discussion}

\section{Preliminary Phytochemical Investigation}

Preliminary phyto-chemical analysis of powdered drug and different extracts of Coccinea Cordifolia root shows the presence of various phyto constituents which are shown in Table 1. 
Table 1: Phytochemical analysis of of powdered root and various extracts of Coccinea cordifolia

\begin{tabular}{|l|l|l|l|l|l|l|l|l|}
\hline $\begin{array}{l}\text { Bioactive } \\
\text { Constituents }\end{array}$ & Powder & $\begin{array}{l}\text { Pet. } \\
\text { Ether }\end{array}$ & Benzene & $\begin{array}{l}\text { Diethyl } \\
\text { Ether }\end{array}$ & Chloroform & Acetone & $\begin{array}{l}\text { Eth. } \\
\text { Acetate }\end{array}$ & Methanol \\
\hline Carbohydrate & + & + & - & + & - & + & - & + \\
\hline $\begin{array}{l}\text { Gums and } \\
\text { Muscilages }\end{array}$ & + & + & - & - & + & - & + & + \\
\hline Proteins & + & - & - & + & - & + & - & - \\
\hline Alkaloids & + & + & + & - & - & + & + & + \\
\hline Glycosides & - & - & - & - & - & - & - & - \\
\hline Saponins & + & + & - & - & - & - & - & + \\
\hline Steroids & + & - & + & - & + & - & + & - \\
\hline Flavonoids & - & - & - & - & - & - & - & - \\
\hline Tanins & + & + & - & + & + & + & - & + \\
\hline Phenolics & + & + & - & - & + & + & - & + \\
\hline Terpenoids & - & - & - & - & - & - & - & - \\
\hline
\end{tabular}

$[+]$ denotes present; [-] denotes absent

\section{Antioxidant Activity of Various Extracts from the Root of Coccinea Cordifolia.}

While evaluating the antioxidant potential of various extracts of Coccinea cordifolia in comparison to the Standard drug, we studied the extracts using four different models. Reducing power assay has again shown increase in absorbance with increase in concentration of various extracts. The activity of methanolic extract at a dose of $100 \mu \mathrm{g} / \mathrm{ml}$ was even better than that of the standard drug at a dose of $1.0 \mu \mathrm{g} / \mathrm{ml}$, which may be a result of additive effect of various phytoconstituents present, the activity of methanolic extract was followed by that of Ethyl acetate and Chloroform extract. The detailed report is shown in Table 2 .

Results for FTC Lipid peroxidation study, here too suggests a dose dependent increase in the peroxidation effect. Among the extracts, methanolic extract was followed by Ethyl acetate extract and benzene extract has shown the least activity. The detailed reports are shown in Table 2 .

For Thio-barbituric Acid method, good percentage inhibition for the methanolic extract has again shown better activity, but was behind the standard drug. The methanolic extract was followed by Benzene extract and ethyl acetate extract respectively, while the chloroform extract has shown the least activity. The results are shown in Table 2.

The Free radical scavenging assay by DPPH method also exhibit good result for the methanolic extract in a dose dependent manner. At the highest dose $(100 \mu \mathrm{g} / \mathrm{ml})$ they have shown $(64.12 \%)$ scavenging activity respectively. Here in this study the lowest activity was shown by methanolic extract as shown in Table 2 .

The results from all the studies and the $\mathrm{IC}_{50}$ values (Table 3) indicated that the methanolic extract from Coccinea cordifolia roots has potential antioxidant property and supports the idea behind the work. The graphical representation of all the activities for various extracts is given in Fig. 1, 2, 3 and 4 respectively. 
[Roy et. al., Vol.6 (Iss.9): September 2018]

(Received: August 23, 2018 - Accepted: September 21, 2018)
ISSN- 2350-0530(O), ISSN- 2394-3629(P)

DOI: $10.5281 /$ zenodo.1443487

Table 2: In vitro free radical scavenging activity of various extract of Coccinea cordifolia roots by RP, TBA, FTC and DPPH methods.

\begin{tabular}{|c|c|c|c|c|c|c|c|}
\hline SI.No & Extracts & Activity & $20 \mu \mathrm{g} / \mathrm{ml}$ & $40 \mu \mathrm{g} / \mathrm{ml}$ & $60 \mu \mathrm{g} / \mathrm{ml}$ & $80 \mu \mathrm{g} / \mathrm{ml}$ & $100 \mu \mathrm{g} / \mathrm{ml}$ \\
\hline \multirow{4}{*}{1} & \multirow{4}{*}{$\mathrm{BZ}$} & $\mathrm{RP}$ & $0.054 \pm 0.05$ & $0.086 \pm 0.05$ & $0.151 \pm 0.002$ & $0.187 \pm 0.05$ & $0.263 \pm 0.001$ \\
\hline & & FTC & $15.54 \pm 0.001$ & $17.44 \pm 0.002$ & $18.82 \pm 0.05$ & $19.67 \pm 0.001$ & $23.24 \pm 0.002$ \\
\hline & & TBA & $30.37 \pm 0.001$ & $35.06 \pm 0.001$ & $41.62 \pm 0.05$ & $47.29 \pm 0.001$ & $52.64 \pm 0.001$ \\
\hline & & DPPH & $11.21 \pm 0.05$ & $13.48 \pm 0.002$ & $15.06 \pm 0.01$ & $18.01 \pm 0.032$ & $24.25 \pm 0.05$ \\
\hline \multirow{4}{*}{2} & \multirow{4}{*}{$\mathrm{DE}$} & $\mathrm{RP}$ & $0.154 \pm 0.001$ & $0.276 \pm 0.002$ & $0.493 \pm 0.001$ & $0.668 \pm 0.05$ & $0.837 \pm 0.05$ \\
\hline & & FTC & $12.12 \pm 0.05$ & $15.35 \pm 0.001$ & $19.38 \pm 0.002$ & $22.12 \pm 0.05$ & $25.29 \pm 0.001$ \\
\hline & & TBA & $13.62 \pm 0.001$ & $19.38 \pm 0.05$ & $29.37 \pm 0.001$ & $35.36 \pm 0.001$ & $43.64 \pm 0.05$ \\
\hline & & DPPH & $13.44 \pm 0.002$ & $15.12 \pm 0.05$ & $18.23 \pm 0.001$ & $21.63 \pm 0.002$ & $28.61 \pm 0.001$ \\
\hline \multirow{4}{*}{3} & \multirow{4}{*}{$\mathrm{CH}$} & $\mathrm{RP}$ & $0.113 \pm 0.002$ & $0.437 \pm 0.001$ & $0.765 \pm 0.002$ & $0.892 \pm 0.05$ & $1.112 \pm 0.05$ \\
\hline & & FTC & $14.49 \pm 0.001$ & $17.01 \pm 0.032$ & $20.06 \pm 0.002$ & $24.25 \pm 0.17$ & $27.63 \pm 0.021$ \\
\hline & & TBA & $17.23 \pm 0.12$ & $21.49 \pm 0.001$ & $27.24 \pm 0.002$ & $32.55 \pm 0.05$ & $41.92 \pm 0.05$ \\
\hline & & DPPH & $9.49 \pm 0.001$ & $11.06 \pm 0.014$ & $15.12 \pm 0.05$ & $19.62 \pm 0.001$ & $20.31 \pm 0.001$ \\
\hline \multirow{4}{*}{4} & \multirow[t]{4}{*}{ EA } & $\mathrm{RP}$ & $0.451 \pm 0.001$ & $0.673 \pm 0.002$ & $0.855 \pm 0.001$ & $1.115 \pm 0.05$ & $1.127 \pm 0.001$ \\
\hline & & FTC & $19.31 \pm 0.05$ & $22.2 \pm 0.002$ & $27.81 \pm 0.05$ & $35.24 \pm 0.001$ & $47.63 \pm 0.002$ \\
\hline & & TBA & $18.37 \pm 0.05$ & $22.49 \pm 0.012$ & $27.34 \pm 0.001$ & $35.55 \pm 0.05$ & $47.81 \pm 0.05$ \\
\hline & & DPPH & $13.84 \pm 0.002$ & $15.92 \pm 0.05$ & $18.82 \pm 0.001$ & $20.12 \pm 0.002$ & $21.12 \pm 0.032$ \\
\hline \multirow{4}{*}{5} & \multirow[t]{4}{*}{ MT } & $\mathrm{RP}$ & $0.697 \pm 0.05$ & $0.781 \pm 0.05$ & $1.392 \pm 0.001$ & $1.721 \pm 0.001$ & $2.015 \pm 0.05$ \\
\hline & & FTC & $40.65 \pm 0.001$ & $46.86 \pm 0.05$ & $56.93 \pm 0.001$ & $60.95 \pm 0.001$ & $71.32 \pm 0.05$ \\
\hline & & TBA & $41.23 \pm 0.001$ & $47.27 \pm 0.002$ & $53.93 \pm 0.001$ & $60.85 \pm 0.002$ & $69.32 \pm 0.05$ \\
\hline & & DPPH & $24.31 \pm 0.05$ & $37.2 \pm 0.002$ & $49.63 \pm 0.001$ & $56.53 \pm 0.001$ & $64.12 \pm 0.002$ \\
\hline \multirow{3}{*}{6} & \multirow{3}{*}{$\begin{array}{l}\text { Ascorbic } \\
\text { acid }\end{array}$} & $\mathrm{RP}$ & $0.093 \pm 0.01$ & $0.279 \pm 0.05$ & $0.837 \pm 0.001$ & $1.286 \pm 0.05$ & $1.893 \pm 0.005$ \\
\hline & & FTC & $38.98 \pm 0.05$ & $54.73 \pm 0.01$ & $65.91 \pm 0.002$ & $70.16 \pm 0.001$ & $78.92 \pm 0.05$ \\
\hline & & TBA & $32.94 \pm 0.001$ & $47.98 \pm 0.05$ & $56.23 \pm 0.01$ & $63.87 \pm 0.001$ & $74.43 \pm 0.05$ \\
\hline
\end{tabular}




\begin{tabular}{|l|l|l|l|l|l|l|l|}
\hline & DPPH & $40.12 \pm 0.001$ & $46.15 \pm 0.05$ & $55.38 \pm 0.002$ & $64.52 \pm 0.001$ & $73.63 \pm 0.05$ \\
\hline
\end{tabular}

Values are mean \pm SEM of 3 replicates

Table 3: IC 50 value from FTC, TBA and DPPH scavenging activity of Coccinea cordifolia

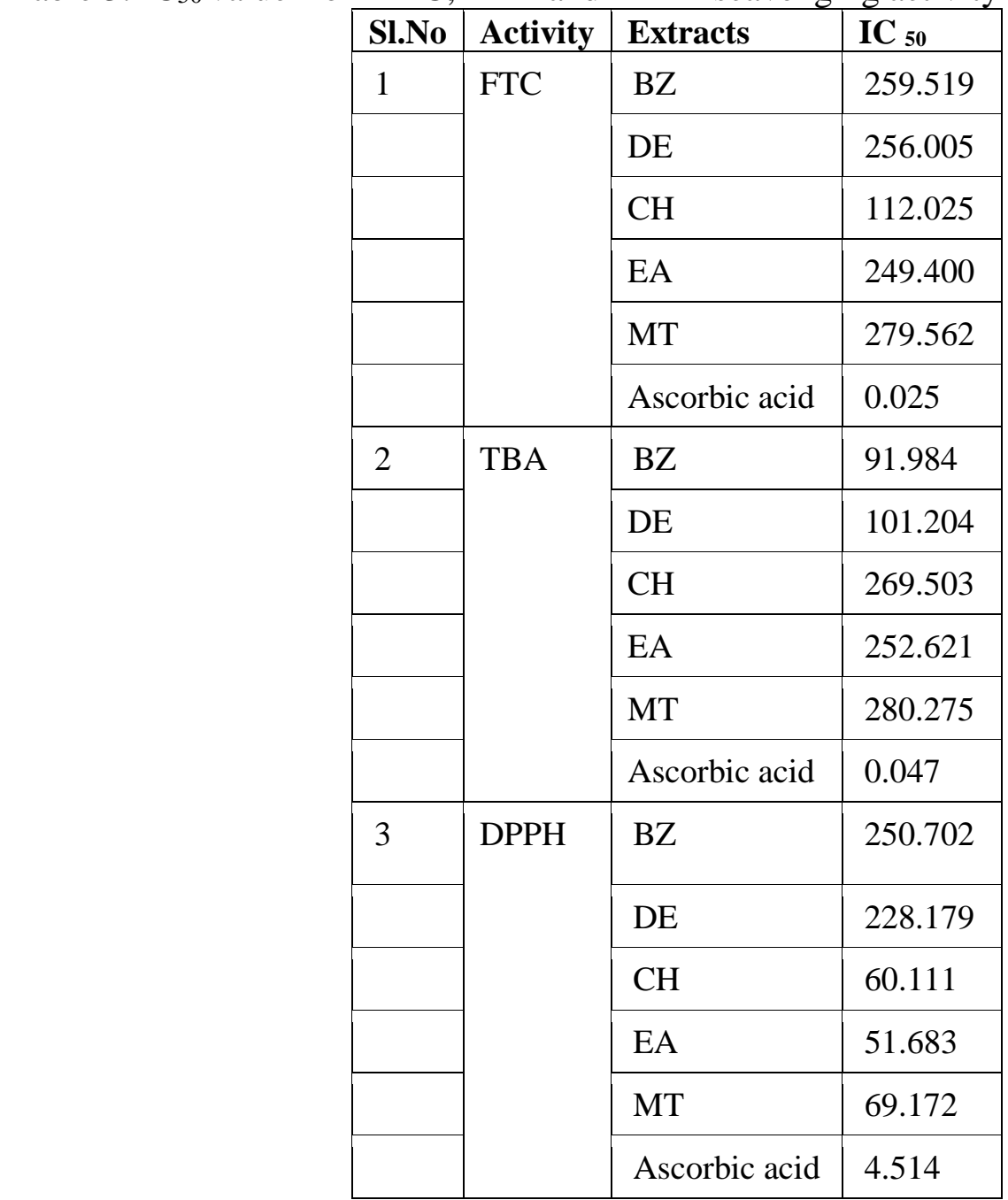

Values are mean \pm SEM of 3 replicates

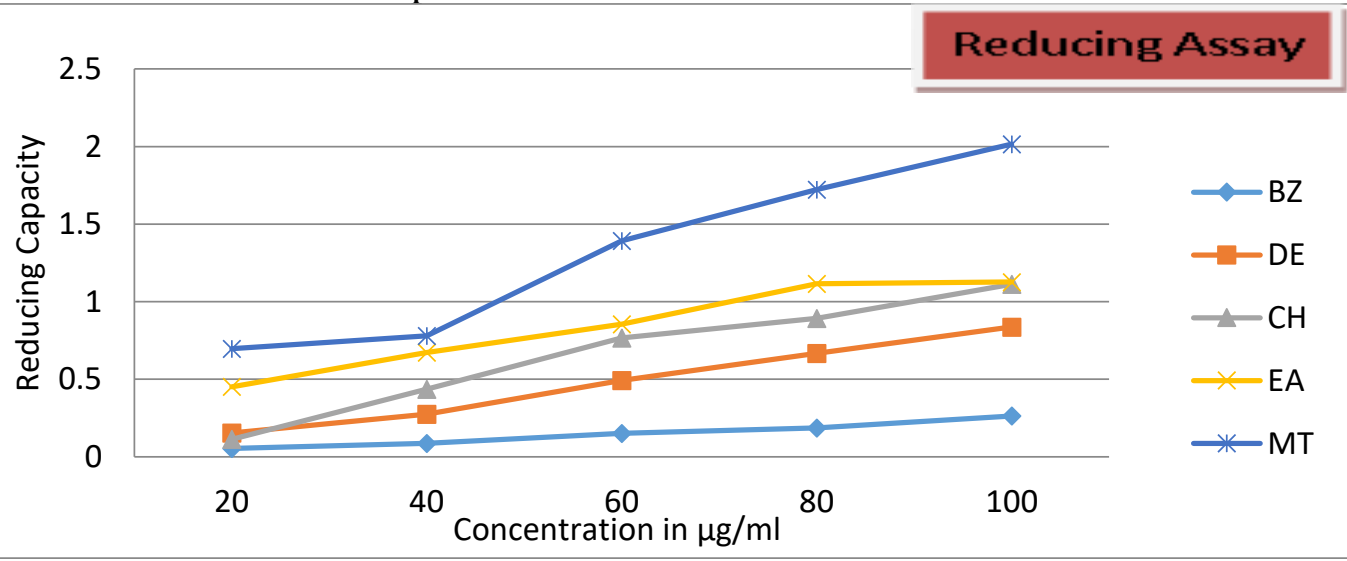

Figure 1: Reducing Power Assay of different extracts of Coccinea cordifolia. 


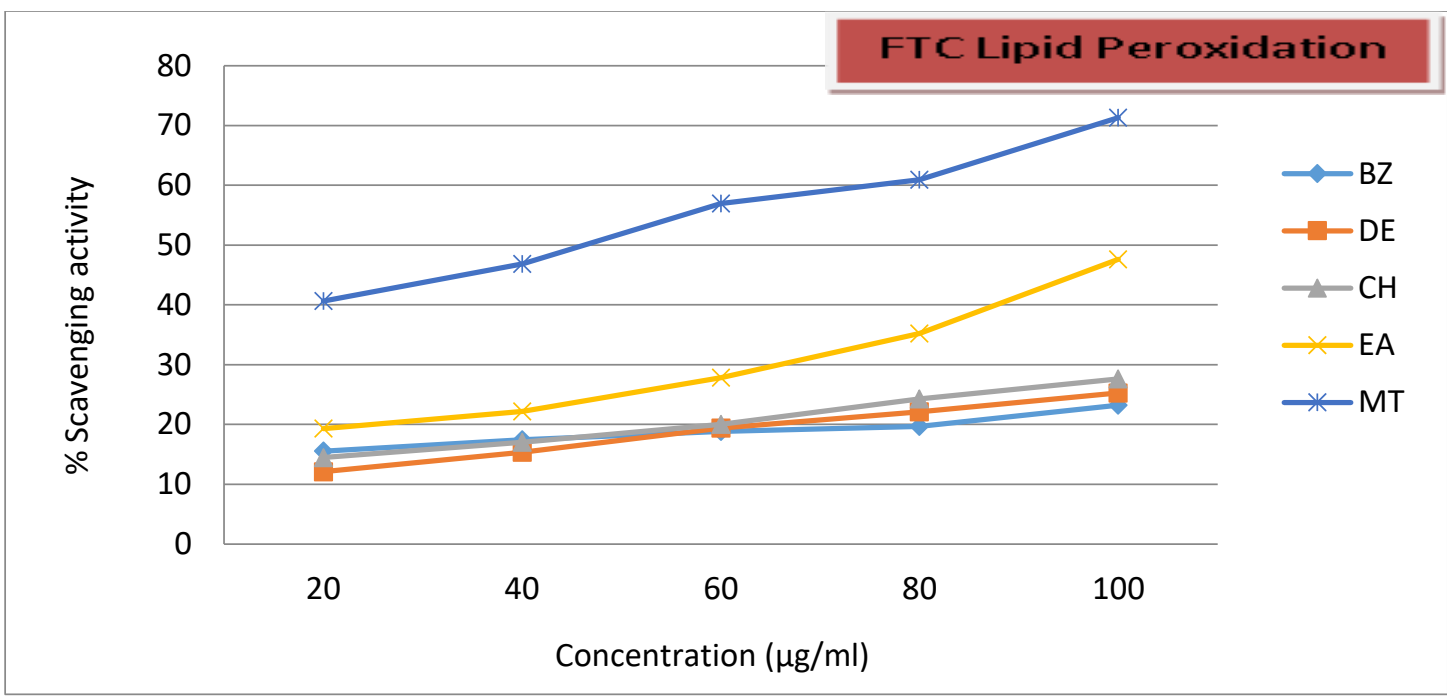

Figure 2: FTC lipid peroxidation study of different extracts of Coccinea cordifolia.

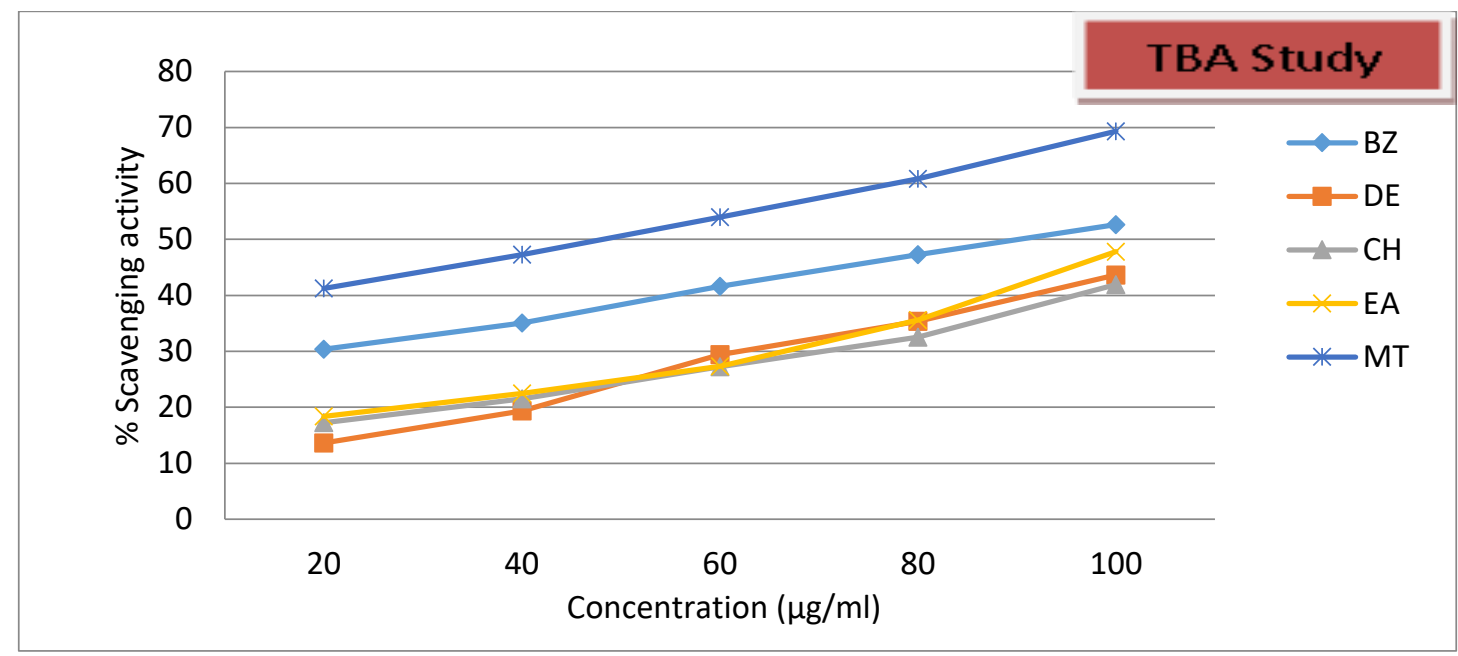

Figure 3: TBA scavenging activity of different extracts of Coccinea cordifolia.

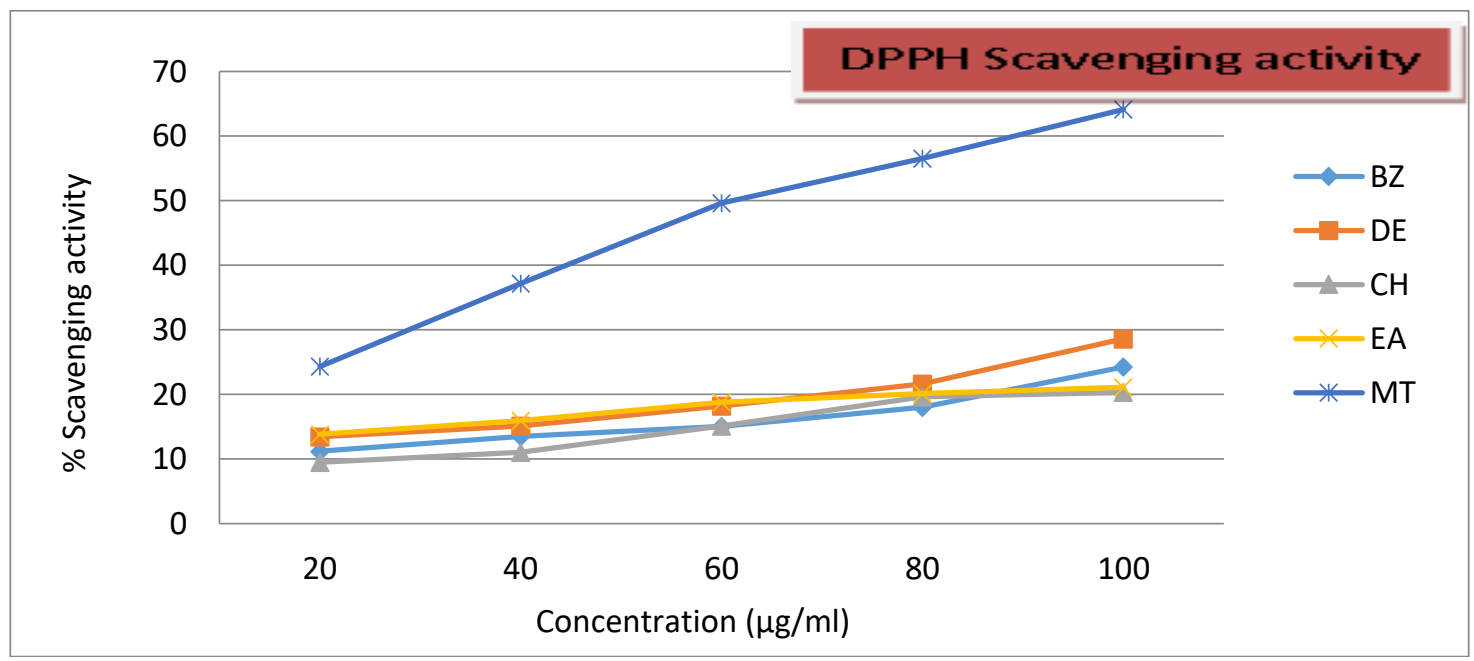

Figure 4: DPPH scavenging activity of different extracts of Coccinea cordifolia. 
Antimicrobial assay and Minimum inhibitory concentration (MIC \pm SD of three replicates) at $600 \mathrm{~nm}$ OD of Methanolic extract of Coccinea cordifolia root.

The results of the antimicrobial assay for methanolic extract of Coccinea cordifolia root (Table 4) shows that, out of 54 bacterial strains, the growth of 34 strains were inhibited by the extract at concentrations within the range of $128-512 \mu \mathrm{g} / \mathrm{ml}, 12$ strains were inhibited at a concentration of $1000 \mu \mathrm{g} / \mathrm{ml}$, while the remaining 08 strains were inhibited at a concentration of $>2000 \mu \mathrm{g} / \mathrm{ml}$, which is the highest concentration for the methanolic extract. The MIC study shows that 10 out of 18 Gram-positive strains were sensitive between 128 and $256 \mu \mathrm{g} / \mathrm{ml}$ (Zone of inhibition 10-16 mm); whereas 14 out of 36 Gram-negative strains were sensitive at a concentration range between 128$256 \mu \mathrm{g} / \mathrm{ml}$ of the chloroform extract (Zone of inhibition 08-16 mm). So we can conclude that, the methanolic extract of Coccinea cordifolia root has shown antimicrobial activity against both Gram-positive and Gram -negative strains.

The results shows antimicrobial potential for the methanolic extract of Coccinea cordifolia root when compared with the standard drug lincomycin, which has shown inhibitory effect against 16 out of 18 strain of Gram Positive and 32 out of 36 of Gram Negative strains at concentration range between $0.25-256 \mu \mathrm{g} / \mathrm{ml}$ with zone of inhibition between $10-18 \mathrm{~mm}$.

Table 4: In vitro antimicrobial assay and Minimum inhibitory concentration (MIC \pm SD of three replicates) at $600 \mathrm{~nm}$ OD of methanolic extract of Coccinea cordifolia root.

\begin{tabular}{|c|c|c|c|c|c|c|c|c|c|c|c|c|c|c|}
\hline \multirow[t]{2}{*}{ Pathogens } & \multirow{2}{*}{$\begin{array}{c}\text { Number } \\
\text { Of } \\
\text { strain }\end{array}$} & \multicolumn{5}{|c|}{ MIC of leaf extracts $(\mu \mathrm{g} / \mathrm{ml})$} & \multirow{2}{*}{$\begin{array}{c}\text { Zone of } \\
\text { inhibition } \\
(\mathrm{mm})\end{array}$} & \multicolumn{7}{|c|}{ MIC of lincomycin $(\mu \mathrm{g} / \mathrm{ml})$} \\
\hline & & 128 & 256 & 512 & 1000 & $>2000$ & & 0.25 & 0.5 & 8 & 64 & 128 & 256 & $>1000$ \\
\hline S. aureus & 07 & 02 & 03 & 01 & - & 01 & ++ & - & 03 & - & 01 & 02 & - & 01 \\
\hline $\begin{array}{l}\text { K. } \\
\text { pneumoniae }\end{array}$ & 06 & - & 03 & 02 & 01 & - & + & 01 & 02 & - & 01 & 01 & 01 & - \\
\hline E. coli & 06 & 01 & - & 02 & 02 & 01 & ++ & 01 & - & 02 & - & 01 & 01 & 01 \\
\hline $\begin{array}{l}\text { Salmonella. } \\
\text { sp }\end{array}$ & 09 & - & 02 & 02 & 03 & 02 & ++ & - & 01 & - & 01 & 02 & 03 & 02 \\
\hline V. cholerae & 07 & 01 & 02 & 01 & 02 & 01 & ++ & 01 & 02 & - & 01 & 03 & - & - \\
\hline B. subtilis & 06 & 02 & - & 01 & 02 & 01 & + & - & 01 & 01 & - & 03 & 01 & - \\
\hline S. faecalis & 05 & - & 03 & 01 & - & 01 & ++ & - & 02 & 01 & - & 01 & - & 01 \\
\hline $\begin{array}{l}\mathrm{P} . \\
\text { aeruginosa }\end{array}$ & 08 & 02 & 01 & 02 & 02 & 01 & ++ & 02 & 01 & - & 01 & 02 & 01 & 01 \\
\hline Total & 54 & 08 & 14 & 12 & 12 & 08 & & 05 & 12 & 04 & 05 & 15 & 07 & 06 \\
\hline
\end{tabular}

Methanolic extract of Coccinea cordifolia; $+: \leq 10 \mathrm{~mm} ;++: \geq 12 \mathrm{~mm}$; the inoculum size used was $10^{5} \mathrm{cfu}$ per spot for all the organisms except S.aureus, where the inoculum size per spot was $10^{6}$ $\mathrm{cfu}$. The result represents the mean value of triplicate tests. 


\section{Conclusion}

The present study has supported the claims of traditional medicine against the plant Coccinea Cordifolia and has shown the potential of methanolic extract of Coccinea Cordifolia root as an antioxidant and antimicrobial agent. The root of the plant can be explored further for isolation of bioactive compound. The ailing humanity needs safer alternatives for healthy life, which was the driving force behind this piece of work.

\section{References}

[1] Http://Www.Ayushveda.Com/Herbs/Coccinia-Indica.Htm\#

[2] Ganga Br, Umamaheswara Pr, Sambasiva Er, Mallikarjuna Tr, Praneeth Dvs. (2011). "Studies On Phyto Chemical Constituents, Quantification Of Total Phenol, Alkaloid Content And In-Vitro AntiOxidant Activity Of Coccinia Cordifolia.” Int. J. Ph. Life Sc., 2(10), 1177-1182.

[3] Percival M. (1996). "Antioxidants". Clin. Nutri. Insghts., 1, 1-4.

[4] Young Is, Woodside Jv. (2001). "Antioxidants in Health and Disease”. J. Clin. Pathol., 54, 176186.

[5] Bawara B, Dixit M, Chauhan Ns, Dixit Vk, Saraf Dk. (2010). "Phyto-Pharmacology of Momordica Dioica Roxb. Ex. Willd: A Review”. Int. J. Phytomed., 2, 1-9.

[6] Ehsan O, Norhani A, Wan Zs, Abdul Ro, Syahida A, Wen K, (2011). "Antioxidant, AntiInflammatory and Anticancer Activities of Methanolic Extracts from Jatropha Curcas Linn". J. Med Plants. Res., 5(1), 49-57.

[7] Jerneja J, Robert V, Franci F. (2009). "Extraction of Phenolic Compounds from Green Walnut Fruits in Different Solvents". Act. Agri. Slove., 93(1), 11-15.

[8] Harborne Jb. (1998). "Phytochemical Methods, A Guide to Modern Technique of Plant Analysis". $3^{\text {rd }}$ Ed. London: Springer (India) Pvt. Ltd; 49-188.

[9] Kokate Ck, Purohit Ap, Gokhale Sb. (2010). "Pharmacognosy". 46 ${ }^{\text {th }}$ Ed. Pune: Nirali Prakashan; A1-A6.

[10] Sreejayan N, Rao Mna. (1997). "Free Radical Scavenging by Curcuminoids". J Pharm Pharmacol , 1997,49, 105-109.

[11] Chang St, Wu Jh, Wang Sy, Kang Pl, Yang Ns, Shyur Lf. (2001). "Antioxidant Activity of Extracts from Acacia Confusa Bark and Heartwood”. J. Agri. Food Chem., 49, 3420-3424.

[12] Ramazan A, Mehmet C, Ensari F. (2001). "Protective Effects of Vitamin E, Selenium and Allopurinol Against Stress-Induced Ulcer Formation in Rats". Turk. J. Med. Sci., 31, 199-203.

[13] Oyaizu M. "Studies on Products of Browning Reactions: Antioxidative Activities of Products of Browning Reaction Prepared from Glucosamine". Jpn. J. Nutr., 44, 307-315.

[14] Hanane E, Nadaya L, Katim A, Yahya C, Abdellah F, Brahim B, Mohammed L. (2011). "Antioxidant Activity, Phytochemical Screening, And Total Phenolic Content of Extracts from Three Genders of Carob Tree Barks Growing in Morocco". Arabian J. Chem., 2, 321-324.

[15] Faten Mae. (2009). "Antioxidant and Anticancer Activities of Doum Fruit Extract (Hyphaene Thebaica)". Afr. J. Pure. App. Chem., 3(10), 197-201.

[16] Peryasamy A, Raj K, Mahalingam K. (2010). "Phytochemical Screening and Antimicrobial Activity from Five Indian Medicinal Plants Against Human Pathogens". Middle East J. Sci Res., 5(6), 477-482.

[17] Jeya Sheela D, Jeeva S, Ramzan Shamila Im, Packia Lekshmi Ncj, Raja Brindha J. (2012). "Antimicrobial Activity and Phytochemical Analysis of Sanseiveria Roxburghiana Leaf". Asian J. Plant Sci. Res., 2 (1), 41-44.

[18] Mahesh B, Satish S. (2013). "Antimicrobial Activity of Some Important Medicinal Plant Against Plant and Human Pathogens”. World J. Agric. Sci., 4, 839-843. 
[19] Estari M, Gujjeti Rp. (2008) "Phytochemical and Antimicrobial Activity of Acmella Paniculata Plant Extracts". J. Bio. Innov., 2(1), 17-22.

[20] Abdullah, N., Khatun, A., (2011). "Evaluation of Phytochemical and Pharmacological Properties of Mikania Cordata (Asteraceae) Leaves”. J. Phramacog. Phytother., 3, 118-123.

[21] Tanti B, Buragohain A K, Gurung L, Kakati D, Das Ak, Borah Sp. (2010). "Assessment of Antimicrobial and Antioxidant Activities of Dendrocnide Sinuata (Blum) Chew Leaves-A Medicinal Plants Used by Ethnic Communities Of North East India”. Ind. J. Nat. Prod. Resour., $1(1), 17-21$.

*Corresponding author.

E-mail address: baharu75@gmail.com 